\title{
Old Literature Learning Strengthens the Character of Prospective Teachers (Needs Assessment Analysis)
}

\author{
Yosi Wulandari ${ }^{1}$ and Wachid Eko Purwanto ${ }^{1}$ \\ ${ }^{1}$ Ahmad Dahlan University, Yogyakarta, Indonesia \\ Email: yosi.wulandari@pbsi.uad.ac.id
}

\begin{abstract}
Based on the achievement of graduate learning formulated by the Association of Indonesian Language and Literature Studies Program, the old literature course is one of the subjects that need to be mastered as an Indonesian teacher candidate. In addition, the jargon of Nawacita that the government wants to realize is to reinforce diversity and strengthen social restoration. However, as the times progressed, the written tradition that became the civilization of the archipelago was no longer used. Even the old literary learning is not yet fully able to cultivate the interest to appreciate the old Indonesian literature. In fact, the presentation of old literary learning with appropriate and relevant teaching materials will provide a complete picture to the students so as to foster a sense of belonging to the old Indonesian literature. Research development of teaching materials is considered necessary so that the old literary learning can strengthen the character of Indonesian teacher candidates. This study begins with a needs assessment survey, followed by analysis of structure and meaning of ancient manuscripts, design of teaching materials, and validation of teaching materials. This paper is prepared to report on survey results related to the needs assessment study.
\end{abstract}

\section{Keywords: Learning, Old Literature, Character, prospective teachers, needs analysis}

\section{INTRODUCTION}

The advancement of the times and technology have an impact on the dynamics of social life in Indonesia. The dominant impact seen is the erosion of the value of local wisdom or the noble value of the nation's culture. This condition is seen in the cases that aired on television, such as the community is easily carried away emotionally, irritable, brutal, rude, even burning vehicles or damaging buildings while rallying. It is, of course, very unfortunate for the progress of the nation, especially to create a young generation of Indonesia who always devoted to God Almighty, wise, intelligent, skilled, virtuous, noble degree, and high civilization. Thus, education as one of the efforts expected to have a psychological orientation to shape the character of the nation.

In relation to these conditions, Law No. 20 of 2003 describes the National Education System explains about the function of education is to develop the ability and build the character and civilization of dignified nation in order to have more inteligent people of the nation and to develop the potential of learners to become a human being who believes and Fear Allah Almighty, be noble, healthy, knowledgeable, capable, creative, independent, 
and become a citizen of democratic and responsible [1]. Therefore, education in Indonesia is required to orient the formation of nation's character, that is education that pay attention to psychiatric education.

Literature is one of the media of psychiatric education. This is because literature has ethical and moral content related to human life. Literature includes psychological, religious, romantic, and sociological issues. In addition, literature was able to explain things from various facets, even many options of literature that can be used as the source of the formation of the nation's character.

The characters defined as psychological, moral or character qualities that distinguish one from another. In other limits, character is a way of thinking and behaving someone to live and work together well in the circle of family, community, nation, or country [2]. Thus, a person is characterized when able to make decisions and take responsibility for decisions made.

Characters in literary texts, literary genres that can be used as a means of characterizing the nation are literary genres that contain values or aspects (1) literary-aesthetic, (2) humanitarian, (3) ethical and morals, and (4) religious-prophetic-philosophy. These four values or aspects are considered capable of optimizing the role of literature in character formation. So, the old literature also has all four values that can shape the character of the nation's children [3].

Old literature is one of the literary genre that has the content of culture and character of the nation. However, in the reality student attention to the old literary text is quite apprehensive. This is also due to the low appreciation of teachers to the old literary texts. Therefore, this condition certainly needs to get attention and increase the appreciation of the old literature.

Meanwhile, local wisdom becomes a thing attached to the old literature. Limitations, local wisdom can be interpreted the wisdom of a society derived from the noble values of culture to regulate the life of society. Sibarani [4] states about local wisdom as follows.

"Local wisdom in cultural traditions such as folklore is divided into local wisdom that aims to increase welfare and which aims to create peace. Local wisdom for welfare includes (1) hard work, (2) discipline, (3) education, (4) health, (5) gotong royong, (6) gender management, (7) cultural preservation and creativity, (8) ) environmental care, while local wisdom for peace includes (1) courtesy, (2) honesty, (3) social solidarity, (4) harmony and conflict resolution, (5) commitment, (6) positive thoughts, and (7) gratitude".

Tjokrowinoto in [5] introduces the term "pancaguna" to describe the old literary benefits as follows. (1) Deepening religious and moral education; (2) increase the love of the homeland; (3) understanding the sacrifices of national heroes; (4) adding to historical knowledge; and (5) are self-reliant and entertaining. Similarly, Haryadi [5] states nine benefits that can be obtained from the old literature, namely as follows. (1) Can serve as entertainment and educational media; (2) its contents can foster the love, pride of the nation and respect for the ancestors; (3) its contents can broaden the horizons of beliefs of customs, and civilization of the nation; (4) performances can foster a sense of unity and 
unity; (5) the creation process fosters a creative, responsive, and dynamic soul; (6) a source of inspiration for the creation of other art forms; (7) the process of its creation is an example of diligent, professional, and humble work; (8) its performance provides a compact and harmonious model of cooperation; and (9) the foreign influences present in it provide an overview of the broad social order and worldview. Thus, both opinions have affirmed that literature has appropriate relevance as a media or learning material to instill character education.

Furthermore, the old literature is one of the subjects taught in universities in the majors or courses of Education of Language and Literature of Indonesia. Old literary learning is taught as a provision for Indonesian teacher candidates. In connection with the required development of teaching materials to achieve learning objectives. The purpose of development of teaching materials is to facilitate the learning process of learners so that require requirements that must be met. These terms are as follows. (1) provides an orientation to the theory, reasoning, and method of applying theory in practice; (2) there are exercises against the use of theory and its application; (3) teaching materials should provide feedback on the exercise; (4) adjusting information and tasks with student development; (5) fostering student interest; (6) explain the learning objectives to the students; (7) increase student motivation; and (8) shows other sources of information [6]. Thus, the purpose of this paper is to describe student needs analysis in old literary learning and to describe the role of old literary learning in character formation.

\section{RESEARCH METHOD}

This research method is survey. Sugiyono [7] explains that the survey method is the method used in the research by using questionnaire as a research tool conducted on large or small population, but the data studied is the data from samples taken from the population so that the relative incidence, distribution and relationship between variable, sociological, and psychological [7]. Population in this research is student of Study Program of Language and Literature of Indonesia. The samples are PBSI students who have followed the old literary restoration. The sample technique is purposive sampling. Through purposive sampling obtained sample of twenty students who meet the assessment standards to be able to provide information about the old literary learning. Data collection techniques used were questionnaires and observations. Questionnaires are given when collected in a class. Observations were made on the learning process and student knowledge. While the data analysis technique used is descriptive qualitative.

\section{RESULTS AND DISCUSSION (NEED ASSESMENT)}

\section{Condition of Old Literary Material}

Based on the questionnaire of the preliminary study results of twenty students, it can be described the condition of old literary material in the form of tables as follows. 
TABLE 1. STUDY INTRODUCTION CONDITION OF OLD LITERARY MATERIAL

\begin{tabular}{llccc}
\hline No. & \multicolumn{1}{c}{ Statement } & Average & Percentage (\%) & Explanation \\
\hline $\mathbf{1 .}$ & $\begin{array}{l}\text { Old Literature teaching materials are hard to } \\
\text { find }\end{array}$ & 3.6 & 90 & Strongly Agree \\
\hline 2. & $\begin{array}{l}\text { Old Literature course material is difficult to } \\
\text { understand }\end{array}$ & 2.65 & 66.3 & Agree \\
\hline 3. & $\begin{array}{l}\text { Old Literature teaching materials used do not } \\
\text { contain ancient manuscripts }\end{array}$ & 2.7 & 67.5 & Agree \\
\hline 4. & $\begin{array}{l}\text { Available Old Literature materials do not } \\
\text { contain transliterations from the original text }\end{array}$ & 3.2 & 80 & Strongly Agree \\
\hline $\mathbf{5 .}$ & $\begin{array}{l}\text { Available Old Literature materials do not } \\
\text { contain transcriptions of the original text }\end{array}$ & 2.9 & 72.5 & Agree \\
\hline $\mathbf{6 .}$ & $\begin{array}{l}\text { Examples of available old literary texts are } \\
\text { elusive }\end{array}$ & 3.3 & 82.5 & Strongly Agree \\
\hline 7. & $\begin{array}{l}\text { Information about the old Minangkabau literary } \\
\text { text is difficult to obtain }\end{array}$ & 3.7 & 92.5 & Strongly Agree \\
\hline 8. $\quad \begin{array}{l}\text { Information about the mantras, prayers, and } \\
\text { azines of the old Minangkabau literature is hard } \\
\text { to know }\end{array}$ & 3.65 & 91.25 & Strongly Agree \\
\hline $\mathbf{9 .}$ & $\begin{array}{l}\text { Information about the manuscript of the } \\
\text { Minangkabau poem is unknown }\end{array}$ & 3.55 & 88.8 & Strongly Agree \\
\hline $\mathbf{1 0 .}$ & $\begin{array}{l}\text { Information about the Kaba Minangkabau text is } \\
\text { unknown }\end{array}$ & 3.45 & 86.3 & Strongly Agree \\
\hline
\end{tabular}

Thus, the information written on the table states that the average student of the PBSI Study Program three agrees and seven strongly agree on the weaknesses in the old literary materials used in the lesson. The statements that are approved by the students are as follows. (1) The material of Old Literature is difficult to understand; (2) Old Literary teaching materials used do not contain ancient texts; (3) Available Old Literature materials do not contain transcriptions of the original text. Furthermore, the statement is considered appropriate by the students, namely (1) Old Literary teaching materials difficult to obtain; (2) Available Old Literature materials do not contain transliterations of the original text; (3) Examples of available old literary texts are elusive; (4) Information on Minangkabau's old literary texts is difficult to obtain; (5) Information about mantras, prayers and azines from the old Minangkabau literature is difficult to obtain; (6) Information about the manuscripts of the Minangkabau poem is unknown; and (7) Information about the text of Kaba Minangkabau is unknown.

In addition to the contents of the statement that has been provided, students also fill out a suggestion / input sheet in relation to the old literary materials needed.

TABLE 2. SUGGESTION/FEEDBACK STUDENT TO OLD LITERARY MATERIAL

\begin{tabular}{cl}
\hline Sample Code & Suggested/Feedback \\
\hline $\mathbf{1}$ & It needs examples of ancient texts from various other regions \\
\hline $\mathbf{2}$ & Old literary materials that contain complete and easy to understand material \\
\hline $\mathbf{4}$ & $\begin{array}{l}\text { With the vast and vastness of old literary material, it is deemed desperately needed } \\
\text { an old literary textbook covering / collecting ancient literary material }\end{array}$ \\
\hline
\end{tabular}


TABLE 2, CONT.

\begin{tabular}{|c|c|}
\hline 5 & Preferably the old literature reference book is easy to get \\
\hline 6 & Books should be easy to get \\
\hline 7 & $\begin{array}{l}\text { The teaching materials of the old literature courses are / are needed to support } \\
\text { teaching and learning activities, in addition to references that may include old } \\
\text { literary material and ancient literature }\end{array}$ \\
\hline 8 & $\begin{array}{l}\text { In the course of the old literature is needed teaching materials as a reference that can } \\
\text { include material about the old literature and ancient literature }\end{array}$ \\
\hline 9 & $\begin{array}{l}\text { By adding a reference so that students can more easily understand the information } \\
\text { about the old literary material }\end{array}$ \\
\hline 10 & $\begin{array}{l}\text { We recommend having a reference book used by students, so that students are not } \\
\text { confused when looking for material }\end{array}$ \\
\hline 11 & $\begin{array}{l}\text { For the old literature in the development of teaching materials are improved again } \\
\text { and made easier for his understanding. In the material are displayed examples. }\end{array}$ \\
\hline 12 & $\begin{array}{l}\text { Students should be given a reference book as a learning material, in the material } \\
\text { more to show examples of real old literature and accurate, reference books used } \\
\text { easily understood }\end{array}$ \\
\hline 13 & $\begin{array}{l}\text { Having a reference book used in the lesson, the reference book used should be easy } \\
\text { to understand }\end{array}$ \\
\hline 14 & $\begin{array}{l}\text { The need to include ancient texts representing one archipelago, the transliteration of } \\
\text { ancient texts to be understood }\end{array}$ \\
\hline 15 & $\begin{array}{l}\text { The old literary material is easy to understand, easy to obtain, and has complete } \\
\text { content (there is original text and contains transliteration and transcription of original } \\
\text { text) }\end{array}$ \\
\hline 16 & As a student, we need old literary materials to support learning \\
\hline 17 & $\begin{array}{l}\text { For the development of old literature materials more complete because so that } \\
\text { students know related to the material and with teaching materials that help students } \\
\text { in knowing the old literature }\end{array}$ \\
\hline 18 & We students are in need of teaching materials to support the courses and tasks given \\
\hline 19 & $\begin{array}{l}\text { With the reference book will facilitate students because the material or materials are } \\
\text { still scattered so indispensable reference book }\end{array}$ \\
\hline 20 & $\begin{array}{l}\text { Old literature materials are expected to be easy to obtain so students can learn easily } \\
\text { and students need to deepen the old literature courses because many of the old } \\
\text { literature contained in learning Indonesian in junior and senior high school or } \\
\text { equivalent. }\end{array}$ \\
\hline
\end{tabular}

Based on suggestions / inputs written by eighteen students it can be concluded that students of Study Program PBSI realize their needs as a candidate Indonesian teachers who must have provision of knowledge of old literature so as to increase literary appreciation in other schools. The main point of the suggestion is the availability of teaching materials complete with examples of ancient texts and explanations of the structure and meaning of the text.

\section{The Contents of Old Literature Teaching Materials Strengthen the Character of Indonesian Language Teachers Candidate}

Based on the analysis of the achievement of Old Literature courses can be explained that the old literary learning has a teaching content that can be used as a reference to strengthen the character of prospective teachers, especially Indonesian language teachers. 
In addition, the analysis is supported by the old literary concepts that have benefits in character formation. The following outlines the achievements of learning courses of Literary Literature from the Book of PBSI Program Curriculum, 2017 [8].

TABLE 3. LEARNING ACHIEVEMENTS OLD LITERATURE

\begin{tabular}{|c|c|c|}
\hline $\begin{array}{ll}\text { Name of } \\
\text { Institution }\end{array}$ & $\begin{array}{l}\text { Course Achievement / Course } \\
\text { Description }\end{array}$ & Teaching Materials \\
\hline $\begin{array}{l}\text { Ahmad Dahlan } \\
\text { University }\end{array}$ & $\begin{array}{l}\text { Students are able to master the concept of } \\
\text { the nature of the old literature; Able to } \\
\text { understand the old literary relationship } \\
\text { with folklore; Able to understand the } \\
\text { function of the old literature; Able to } \\
\text { connect the old literary periods; Able to } \\
\text { master the concept of Old Malay } \\
\text { literature; Able to master the concept of } \\
\text { ancient Javanese literary variety; Able to } \\
\text { master the concept of Variety able to } \\
\text { master the concept of the function of the } \\
\text { old literature review; Able to master the } \\
\text { concept of the transfer of old literary } \\
\text { rides; Able to master the concept of old } \\
\text { literature and its relation in learning } \\
\text { Indonesian language }\end{array}$ & $\begin{array}{l}\text { 1. Old literary relationship with } \\
\text { folklore } \\
\text { 2. Old literary functions } \\
\text { 3. Periods of old literature } \\
\text { 4. Variety of old literature (Malay) } \\
\text { 5. Variety of old literature (Java) } \\
\text { 6. The function of the old literature } \\
\text { review } \\
\text { 7. Transfer old literary rides } \\
\text { 8. The concept of teaching the old } \\
\text { literature of learning Indonesian at } \\
\text { school }\end{array}$ \\
\hline
\end{tabular}

The table illustrates that the old literature courses taught to students are not limited to literary knowledge. The learning achievement is intended to characterize teachers' character as well as to strengthen the understanding of local wisdom. In addition, the introduction to the old literary concepts in detail also provides the utility for prospective teachers to teach the old literature in field practice.

Furthermore, the teaching materials that were taught in the form of an intensive introduction to students with old literary texts so as to foster an appreciation of the old literature. Literature with its function dulce et utile, which is beautiful and useful is expected to give confidence for society to role of literature in character forming. Based on aspects of composition, literature is arranged in a neat and interesting form that makes people happy to read, hear, see, and enjoy it.

Old literary learning for prospective teachers is also directed at the growth of appreciative attitude towards literature. It can be observed in the field of achievements and old literary teaching materials. Literary literature cultivates literary (cognitive) literary knowledge of love for literary works (affective), and trains the skill of producing literary works (psychomotor). In addition, appreciative activities can be done with receptive activities, namely reading and listening to literary works, watching the works of literature, productive, and documentative. Literary appreciation activities train the mind, feelings, and motor skills so that the mind becomes critical, feelings of being sensitive, and smooth, and well-trained motor skills. Thus, the objectives of the old literary learning become the basic capital in the development of character education.

In relation to these findings, Solin asserts about the benefits of the old literature in character formation. Solin explains that the Indonesian people's personality is inspired from 
Indonesian Literature as a source of inspiration for the realization of nation, language, and motherland of Indonesia. Thus, reading Indonesian literature to literary literature is believed to strengthen the identity and personality of Indonesia [9].

Furthermore, Kanzunuddin in his research results explain the literature as a medium of learning can be exploited receptively and expressively as an effort to character education. Utilization can be done with two steps, namely the selection of teaching materials and management of the learning process. The literary works chosen as teaching materials are works of quality, meaning both aesthetically and ethically. In addition, literary works should also be good in structural construction and contain values that can guide learners to become better human beings [10].

\section{CONCLUSION}

Based on the results of the survey and analysis it can be concluded that the old literary learning has not used the teaching materials complete with examples of text and transliteration. In addition, old literary literature materials are also difficult to obtain. Students' understanding of the old literary material is still low. Furthermore, the achievement of learning contained in the semester learning plan also has directed the achievement of the government's jaws to form a generation of characterized nations. Therefore, it is necessary to develop the old literary materials so that they can be used in the old literature courses.

\section{REFERENCES}

[1] Law of the Republic of Indonesia Number 20 Year 2003, "Law of the Republic of Indonesia Number 20 Year 2003.".

[2] Tim Penyusun, Kamus Besar Bahasa Indonesia. https://kbbi.kemdikbud.go.id/, 2017.

[3] D. Saryono, Dasar Apresiasi Sastra. Yogyakarta: Elmatera Publishing, 2009.

[4] R. Sibarani, "Folklor sebagai Media dan Sumber Pendidikan: Sebuah Ancangan Kurikulum dalam Pembentukan Karakter Siswa Berbasis Nilai Budaya Batak Toba," in Folklor Nusantara Hakikat, Bentuk, dan Fungsi, S. Endraswara, Ed. Yogyakarta: Ombak, 2013.

[5] Haryadi, Sastra Melayu. Yogyarta: IKIP Yogyakarta, 1994.

[6] J. Mblu dan Suhartono, Pengembangan Bahan Ajara. Malang: Elang Mas, 2004.

[7] Sugiyono, Metode Penelitian Pendidikan (Pendekatan Kualitatif, Kuantitatif, dan R\&D). Bandung: Alfabeta, 2013.

[8] Tim Penyusun, Kurikulum Prodi Pendidikan Bahasa dan Sastra Indonesia, Universtias Ahmad Dahlan. 2017.

[9] M. Solin, "Peranan Bahasa Indonesia Dalam Membangun Karakter Bangsa," J. Fak. Bhs. dan Seni Univ. Negeri Medan, vol. http://dig, hal. 1-10, 2010.

[10] M. Kanzunnudin, "Peran Sastra Dalam Pendidikan Karakter," http://eprints.umk.ac.id/384/1/PROSIDING_SEMINAR_NASIONAL_PENDIDIKAN_(PENDIDIKAN _UNTUK_KEJ.205-214.pdf, hal. 195-204. 